\title{
Exploring plastic and genetic responses to temperature variation using copper butterflies
}

\author{
K. Fischer*, I. Karl \\ Zoological Institute and Museum, University of Greifswald, Johann-Sebastian-Bach-Str. 11/12, 17489 Greifswald, Germany
}

\begin{abstract}
Variable thermal environments experienced by most organisms warrant mechanisms to adjust the expression of phenotypic values to environmental needs. Here we explored short- (mainly developmental plasticity) and long-term effects (genetic differentiation across altitudes) of temperature variation using copper butterflies as model organisms. Lower compared to higher developmental temperatures yielded predictable variation by increasing development time, body size, total food consumption, the efficiency of converting digested food into body matter, and cold stress resistance, but decreasing daily food consumption, assimilation efficiency, body fat and protein content, weight loss at metamorphosis, the proportion of directly developing individuals, pupal melanisation and heat stress resistance. While variation in temperature stress resistance and developmental pathways is likely to reflect adaptive phenotypic plasticity, the reasons underlying variation in other traits are less clear. High-altitude populations showed increased development time, egg size, flight performance, wing and pupal melanisation and cold stress resistance, but decreased body fat content and heat stress resistance, compared to low-altitude populations. The differences seem to be mainly caused by thermal adaptation and seasonal time constraints. Cold stress resistance was related to variation at the phosphoglucose isomerase locus, and variation in heat stress resistance showed patterns similar to variation in the expression of stress-inducible heat shock proteins. High-altitude populations showed clearly reduced plasticity in heat stress tolerance, which may pose a substantial problem, given the rising temperatures at a global scale.
\end{abstract}

KEY WORDS: Thermal adaptation - Altitudinal variation - Temperature stress resistance · Temperature-size rule $\cdot$ Life-history plasticity $\cdot$ Lycaena sp. $\cdot$ Phosphoglucose isomerase $\cdot$ PGI

Resale or republication not permitted without written consent of the publisher

\section{DEALING WITH TEMPERATURE VARIATION}

Temperature is one of the most important ecological factors affecting life directly and indirectly at all spatial and temporal scales (Johnston \& Bennett 1996, Angilletta \& Dunham 2003, Clarke 2003, 2006, Hoffmann et al. 2003, Sinclair et al. 2003). Most organisms experience highly variable thermal environments throughout their lives, and this poses substantial challenges for key elements of fitness such as survival and reproduction (Dahlhoff \& Rank 2007); therefore, temperature is considered an important selective agent (Clarke 2003, Hoffmann et al. 2003). To counter negative effects of both temperature variation and temperature extremes, all organisms rely on the capability to adjust the expression of phenotypic values to environmental needs.
Consequently, the evolution of behavioural, physiological and molecular mechanisms to cope with stressful thermal conditions is expected and generally found (Hoffmann et al. 2003, Sørensen et al. 2003).

Conceptually, mechanisms to adjust phenotypic expression can be categorized into 2 classes: genetic adaptation (e.g. through changes in allele frequencies) and phenotypic plasticity (Bradshaw 1965, Pigliucci 2001). Phenotypic plasticity represents direct environmental effects on the phenotype, which may be an adaptive strategy to cope with short-term environmental variation, or may alternatively be a non-adaptive biochemical or physiological interaction of an organism with its environment (Bradshaw 1965, Pigliucci 2001). Not unexpectedly, animals show a wealth of short-term responses to temperature variation (cf. Kjærsgaard et 
al. 2010, this Special; Fig. 1). The fastest way to respond to unfavourable temperature is behavioural change. Such responses include, for example, behavioural thermoregulation to gain warmth through sun basking or to avoid overheating by moving into the shade (e.g. Clench 1966, Douwes 1976, Kingsolver \& Watt 1984, Van Dyck \& Matthysen 1998). Thus behavioural adjustment is extremely quick and efficient and may change the body temperature of ectotherms by several degrees within seconds (Karl et al. 2009c), though naturally there are limitations imposed by the availability of favourable sites that are within easy reach. Although generally fast, behavioural responses may extend to several months (e.g. in migratory organisms; Dockx et al. 2004, Brower et al. 2009).

Other plastic responses include rapid hardening, adult acclimation and developmental plasticity. Rapid hardening refers to enhanced survival under temperature extremes after a brief pre-exposure to less extreme temperatures, as described in several insect species and some other arthropods (e.g. Lee et al. 1987, Kelty \& Lee 1999, 2001, Sejerkilde et al. 2003, Sinclair et al. 2003, Marais et al. 2009). To induce hardening, pre-exposure times of a few hours are needed (e.g. 1 to 2 h; Lee et al. 1987, Bahrndorff et al. 2009). Adult acclimation, in turn, is defined as a reversible, facultative response to changes in a single environmental variable in the adult stage (Willmer et al. 2000, Wilson \& Franklin 2002). Acclimatory responses to temperature, e.g. in temperature stress resistance, can be typically expected within several hours to days (Zeilstra \& Fischer 2005, Geister \& Fischer 2007). Developmental plasticity, in contrast, refers to a usually non-reversible cascade of phenotypic changes due to differences in the developmental environment (Willmer et al. 2000, Wilson \& Franklin 2002). Such responses typically need several days to take effect, and may also affect stress resistance traits such as chill-coma recovery time and heat knockdown time (Zeilstra \& Fischer 2005, Geister \& Fischer 2007, Karl et al. 2008a). From the above it should be evident that there is not necessarily a strict distinction between the different categories,

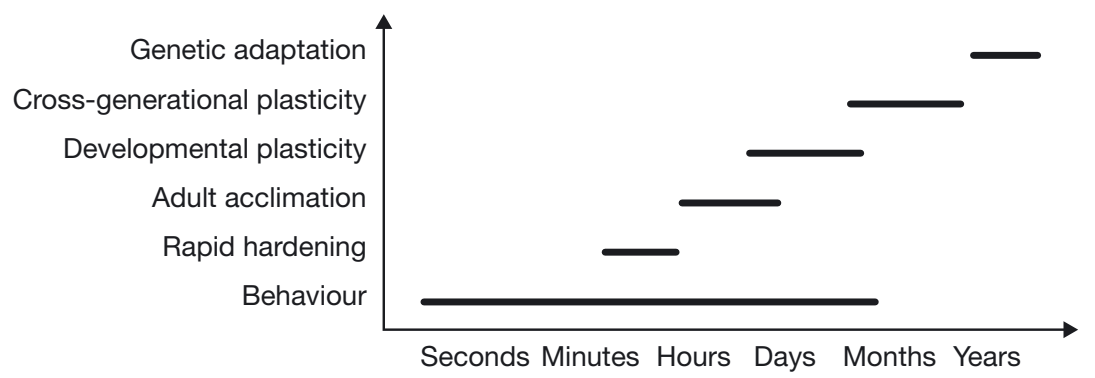

Fig. 1. Mechanisms of response to temperature variation, exemplified for arthropods. All mechanisms except genetic adaptation reflect different types of environmentally induced phenotypic plasticity which are mainly used for didactic purposes (Fig. 1). While acclimation and developmental plasticity are clearly distinguished by occurring at different life stages, hardening may occur in either life stage and is mainly characterized by its rapidity, thus reflecting one end of a putatively continuous response.

In addition to the plastic responses detailed above, the individual phenotype is sometimes affected by the environmental experience of other individuals (Mousseau \& Dingle 1991, Mousseau \& Fox 1998). Such cross-generational plasticity most frequently involves interactions between mothers and their offspring, and has also been demonstrated in relation to temperature (maternal effects; Mousseau \& Fox 1998, AmarilloSuárez \& Fox 2006, Steigenga \& Fischer 2007, Kjærsgaard et al. 2010, this Special, Scharf et al. 2010, this Special). Finally, spatial and/or temporal temperature variation may, over the long term, induce evolutionary (genetic) adaptation. In particular, genetically determined variation in traits related to fitness along geographic gradients are thought to be the result of such adaptive evolution (e.g. Hoffmann et al. 2002, 2005, Castañeda et al. 2005, Collinge et al. 2006, Sambucetti et al. 2006, Rezende et al. 2010, this Special). Because of the strong covariance between temperature and geographic clines, analyzing clinal variation has become a key element in investigating adaptive (thermal) evolution (Bubliy \& Loeschcke 2005, Sambucetti et al. 2006, Karl et al. 2008a, 2009a, de Jong et al. 2010, this Special).

To sum up, the central issue addressed here-viz. how organisms adapt to complex (thermal) environments involving the above mechanisms - lies at the very heart of ecology and evolutionary biology. Moreover, facing the ubiquitous effects of rapid humaninduced global warming (e.g. Parmesan et al. 1999, Hitch \& Leberg 2007), investigating how organisms deal with temperature variation becomes an ever more important task. This is because deteriorating thermal conditions will force organisms to either adapt to such environmental change, or perish (Angilletta et al. 2002, Helmuth 2002, Dahlhoff \& Rank 2007, Chown et al. 2010, this Special, Van Doorslaer et al. 2010, this Special). In this context it should be stressed that the ability to cope with temperature extremes rather than different mean temperatures is probably of much greater relevance for species survival and thermal adaptation (Anderson et al. 2003, Bijlsma \& Loeschcke 2005, Chown et al. 2010). Consequently, recent efforts to more comprehensively understand the consequences of thermal variation have often focussed on the responses to temperature extremes; these efforts have yielded some remarkable pro- 
gress, e.g. regarding the role of heat shock proteins (see Yahara 1999, Sørensen et al. 2003).

In the present review we highlight some plastic and genetic responses to temperature variation, focussing on the temperature-size rule and altitudinal variation in life-history and stress-resistance traits. For this purpose we used copper butterflies Lycaena sp., which have been used extensively as study organisms in the context of thermal adaptation in our laboratory over recent years (see below). The review is not meant to be exhaustive, but rather highlights selected features.

\section{MODEL ORGANISM: COPPER BUTTERFLIES}

Copper butterflies represent a well-defined tribus within the family Lycaenidae (Lepidoptera), with roughly 100 extant species (Bridges 1988). Males are typically brightly coloured (e.g. orange-red, violet), while females are often much less conspicuously brownish (sexual dichroism; Tolman \& Lewington 1998). These small butterflies are ecologically interesting as many species show substantial population declines in response to human-induced habitat deterioration (e.g. Duffey 1977, Nicholls \& Pullin 2000, Bauerfeind et al. 2009). In Europe and adjacent areas, for instance, there are 16 extant species, 5 of which show recent population declines (Van Swaay \& Warren 1999).

Since 1970s, copper butterflies have been repeatedly used to address questions in relation to thermal adaptation and other issues. In pioneering studies, Douwes $(1975,1976)$ comprehensively investigated the population structure and behavioural thermoregulation of Lycaena virgaureae, followed by studies on the territorial behaviour of L. hippothoe (Fischer \& Fiedler 2001a, Turlure \& Van Dyck 2009). Fischer \& Fiedler (2001a) revealed a remarkable degree of plasticity in matelocating tactics, with males displaying resource-based territoriality throughout, but changing from perching to patrolling behaviour in increasingly beneficial weather conditions. Further, copper butterflies were used to study the control of seasonal morph determination (Endo \& Kamata 1985, Endo et al. 1985) and the dynamics of ecdysone rhythms (Endo \& Shibata 1987). A series of studies investigated plasticity in life-history traits and life cycles in response to temperature and other environmental variables in $L$. tityrus and L. hippothoe (e.g. Fischer \& Fiedler 2000a,b, 2001b,c, 2002a, Fischer et al. 2004, Karl \& Fischer 2008), while others focussed on altitudinal variation and the functional significance of allelic variation at the phosphoglucose isomerase (PGI) locus (Karl et al. 2008a,b, 2009b). Finally, copper butterflies were used to address questions within a conservation context, e.g. habitat use and mortality factors in the wild (L. dispar; Nicholls \& Pullin
2000, Martin \& Pullin 2004), and for exploring metapopulation dynamics (L. helle; Fischer et al. 1999, Bauerfeind et al. 2009) and population genetic structure (L. helle; Finger et al. 2009). For instance, L. tityrus suffers from an increased nitrogen content of its food plant through increased mortality and reduced body mass, despite accelerated development (Fischer \& Fiedler 2000a). This finding may have major implications for the conservation of rare insects in grassland ecosystems.

The above examples illustrate the rather broad range of questions addressed using copper butterflies, which have proved to be suitable model organisms in the given contexts. However, an obvious question remains: Why use these rather rare and nowadays often declining butterflies rather than an established model organism? One advantage might be that the ecology of copper butterflies, including habitat preferences and mating behaviour, is well understood (see above). However, other aspects seem even more relevant. Note in this context that much advancement in modern biology relies on a small number of typically common and widespread species. Models such as Drosophila melanogaster, Caenorhabditis elegans and house mice, being investigated in depth, are absolutely indispensable to scientific progress (Bolker 1995, Flannery 1997). However, regardless of the exciting progresses achieved, we do need a certain taxonomic breadth in order to generalize the results obtained from model species. Regarding our current knowledge on thermal adaptation, for instance, it is largely unclear whether and to what extent the knowledge is transferable to rarer species such as those of conservation concern. In that respect, copper butterflies and other organisms may add valuably to the current picture.

The data presented below originate from 2 different species, Lycaena tityrus (Poda, 1761) and L. hippothoe (L.), which are temperate zone butterflies ranging from Western Europe to central Asia and from northern Spain to easternmost Siberia and China, respectively (Ebert \& Rennwald 1991). While L. tityrus is typically bivoltine with 2 discrete generations per year (although populations with 1 or 3 generations occur), $L$. hippothoe has only 1 generation per year throughout its range, except for the western Hungarian bivoltine population (Tolman \& Lewington 1998, Fischer \& Fiedler 2002a). Both species hibernate as half-grown larvae. The principal larval host plant for both is Rumex acetosa L. (Polygonaceae), a common and widespread perennial herb, though at least L. tityrus also uses some congeneric plant species such as $R$. acetosella L. and R. scutatus L. (Ebert \& Rennwald 1991, Tolman \& Lewington 1998). Both species inhabit wetlands as well as different types of unimproved grassland. 


\section{PLASTIC AND GENETIC RESPONSES TO TEMPERATURE VARIATION}

\subsection{Temperature-mediated plasticity: patterns, significance and mechanisms}

\subsubsection{Plastic responses}

Along with many other organisms, copper butterflies show a wealth of plastic responses to variation in ambient temperature (Table 1). As is generally the case in ectothermic animals, higher temperatures reduce development time and body size, but increase larval growth rates (Atkinson 1994, Fischer \& Fiedler 2000b, 2001b, 2002a, Atkinson et al. 2006, Karl \& Fischer 2008). Additionally, temperature also affects body composition, with body fat and protein content increasing with increasing temperature, thus indicating favourable growth conditions at warmer temperatures (Karl \& Fischer 2008). Temperature may also have striking effects on butterfly life cycles, with higher temperatures increasing the proportion of direct developers (in Lycaena tityrus and L. hippothoe), and reducing the number of larval instars in the bivoltine populations of L. hippothoe (Fischer \& Fiedler 2001b, 2002a). The latter is obviously an adaptive mechanism to further speed up development if environmental conditions indicate potential for adding an additional generation per year (Fischer \& Fiedler 2001b, 2002a). The shorter development time found in directly developing in contrast to diapausing individuals is typically associated with a reduction in body size (Fischer \& Fiedler 2001b,d, 2002a). Further, temperature affects the instar

Table 1. Lycaena sp. Relative differences in life-history and other traits across low and high developmental temperatures in copper butterflies. The putative (selective) forces responsible for the variation found are given in the last column. T: temperature; $\uparrow:$ increased; $\downarrow$ : decreased

\begin{tabular}{|lccll|}
\hline Trait & Low T & High T & Selective force \\
\hline Development time & $\uparrow$ & $\downarrow$ & Physiological constraint \\
Body size & $\uparrow$ & $\downarrow$ & Unclear \\
Daily food consumption & $\downarrow$ & $\uparrow$ & Physiological constraint \\
Total food consumption & $\uparrow$ & $\downarrow$ & Unclear \\
Assimilation & $\downarrow$ & $\uparrow$ & Physiological constraint \\
Efficiency to convert digested & $\uparrow$ & $\downarrow$ & Unclear, constraint? \\
food in body matter & & & \\
Body fat content & $\downarrow$ & $\uparrow$ & Unclear, cold stress? \\
Body protein content & $\downarrow$ & $\uparrow$ & Unclear, cold stress? \\
Weight loss at metamorphosis & $\downarrow$ & $\uparrow$ & Cost of fast growth \\
Number of larval instars & $\uparrow$ & $\downarrow$ & Change in voltinism \\
Direct development & $\downarrow$ & $\uparrow$ & Change in voltinism \\
Overwintering stage (larval & $\downarrow$ & $\uparrow$ & Exploiting favourable \\
instar) & $\downarrow$ & $\uparrow$ & conditions \\
Pupal melanisation & $\downarrow$ & $\uparrow$ & Unclear, UV protection? \\
Cold stress resistance & $\uparrow$ & $\downarrow$ & Temperature \\
Heat stress resistance & $\downarrow$ & $\uparrow$ & Temperature \\
\hline
\end{tabular}

of hibernation in monovoltine populations of L. hippothoe, changing from third instar to the fourth instar with increasing temperature (Fischer \& Fiedler 2002a). At cold temperatures, even a facultative biennialism seems possible in alpine populations of $L$. hippothoe (Fischer \& Fiedler 2002a). Higher temperatures induce increased pupal melanisation for currently unknown reasons, though enhanced UV protection might be of particular importance (Karl et al. 2009c). Finally, stress resistance traits are affected by ambient temperature, with cold and heat stress resistance increasing through exposure to cold and warm temperatures, respectively (Zeilstra \& Fischer 2005, Karl et al. 2008a; see also Section 3.2.4. below). Such responses in temperature stress tolerance can be induced during both the larval (=developmental plasticity) and the adult (=acclimation) stages in L. tityrus (Zeilstra \& Fischer 2005).

\subsubsection{Sex- and population-specific differences in the temperature-size rule}

A pattern of particular interest here is the temperature-size rule, referring to the common pattern of a negative relationship between developmental temperature and adult size in ectotherms (Atkinson 1994). Despite much effort over recent years, the temperaturesize rule has remained enigmatic (e.g. Blanckenhorn 1997, Partridge \& Coyne 1997, Angilletta et al. 2004, Atkinson et al. 2006, Cabanita \& Atkinson 2006, Walters \& Hassall 2006, Karl \& Fischer 2008). Importantly, there is hardly any support for an adaptive explanation involving the demonstration of fitness advantages of being larger or maturing later at lower temperatures, and the underlying developmental mechanisms are also largely unknown (Karl \& Fischer 2008).

Against this background we have investigated whether thermal reaction norms (i.e. the temperature-size rule) differ across sexes and populations of copper butterflies. While a lack of such variation may indicate a common underlying mechanism and thus speak in favour of a physiological constraint, the opposite would suggest that, at least if consistent with a priori predictions based on optimality, natural selection operates on such reaction norms and is therefore able to reshape and modify such fundamental patterns if selectively favoured (cf. Trotta et al. 2010, this Special).

In directly developing individuals of both Lycaena tityrus and L. hippothoe, we found indeed sexual differences in 
thermal reaction norms. Female body size responded less strongly to temperature variation than males body size (Fischer \& Fiedler 2000b, 2001a, but see Karl \& Fischer 2008; Fig. 2). Such a difference had been predicted based on sexual selection theory. Using a temperature gradient, we pushed larval growth rates towards their physiological upper limit in order to reveal otherwise masked trade-offs. Throughout the temperature range, larval development time of males was shorter compared to that of females (facilitated by invariably higher growth rates), as was predicted by protandry theory (Wiklund \& Fagerström 1977, Fagerström \& Wiklund 1982). Nevertheless, males were able to achieve similar body sizes to those of females at lower temperatures due to plastic growth (Fischer \& Fiedler 2000b, 2001a). At high temperatures, in contrast, where growth rates were close to their physiological limits, males were forced into a trade-off in which they favoured early emergence over large size, leading to a substantial weight loss. The reasoning behind our prediction here was that, with increasing temperatures, it should become increasingly difficult for males to achieve a developmental advantage compared to females. Weight of females, however, remained similar throughout, presumably caused by fecundity selection for large body size (Honek 1993, Roff 2002). Thus, in accordance with theory, our results suggest a selective premium on body size in females, but a selective premium on rapid development in males.
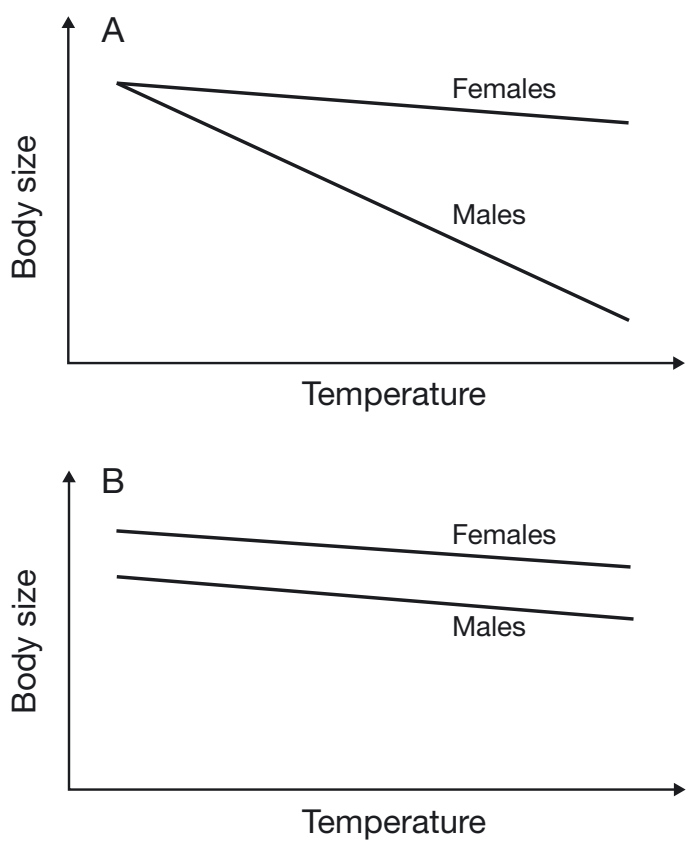

Fig. 2. (A) Sex-specific thermal reactions in oligovoltine populations of copper butterflies and (B) lack thereof in monovoltine populations (based on data published in Fischer \& Fiedler 2000b, 2001a, 2002b)
Three issues are of importance here. (1) Thermal reaction norms show sex-specific variation in a predictable manner, suggesting adaptive adjustment. (2) Sex-specific differences in thermal reaction norms reflect divergent selective pressures on males and females. (3) Given that body size is under positive selection, a pronounced reduction in body size at high temperatures should only be expected under time constraints, where compensatory mechanisms buffering change are likely to be insufficient (as shown here for time-constrained protandrous males at high temperatures; Fischer \& Fiedler 2000b, 2001a).

Following up on the third issue, we predicted a qualitative difference to the patterns described above in less time-constrained populations, i.e. those always developing indirectly (i.e. diapausing) under natural conditions. These (near) obligatorily monovoltine populations are less time-constrained compared to other populations, as evidenced by a substantially longer development time in common garden experiments (Fischer \& Fiedler 2002a, Karl et al. 2008a). Consequently, we predicted for these populations: (1) a weaker response of body size to increasing temperature, and (2) a lack of sex-specific differences (Fischer \& Fiedler 2002b). The latter follows from the fact that body size is also important for males (cf. the similar body size for males and females at a low temperature despite a shorter development time in males; as described above), and because a trade-off between earlier male emergence and body size was only evident under substantial time stress (Fischer \& Fiedler $2001 b, 2002 a)$. This reasoning is in agreement with the compound interest hypothesis (Fischer \& Fiedler 2002b). Accordingly, multivoltine species with relatively short generation times should gain high compound interest benefits from reproducing early at high temperatures, gaining extra generations, even at the expense of being smaller. This is because the disadvantage of a smaller size will be overcompensated by an additional reproductive cycle (Fischer \& Fiedler 2002b). However, this should not apply for obligatorily monovoltine populations, as is the case here. Therefore, we explicitly tested the prediction that monovoltine populations (no compound interest) should be selected for large body size to maximise adult fitness regardless of temperature.

The concomitant results were in broad agreement with these predictions (Fig. 2). In 2 monovoltine populations of Lycaena hippothoe, increasing temperatures had no significant effect on pupal weight and caused a slight decrease in adult weight only (Fischer \& Fiedler $2002 b$ ). Additionally, there was no indication of any sex-specific differences in reaction norms. Thus the results support our predictions, indicating that time constraints, in association with the compound interest 
effect, largely determine the relationship between temperature and insect size at maturity. Differences in growth rates among sexes, populations and temperatures were generally associated with an analogous variation in the weight loss at metamorphosis. Thus weight loss increased with increasing temperature, was higher in more rapidly developing populations than in more slowly developing ones, and was higher in males than in females (Fischer et al. 2004). This has been interpreted as a physiological cost of rapid growth, with the payoff of accelerated growth being reduced by a disproportionally smaller adult size (Fischer et al. 2004). In males, a $6 \%$ higher metabolic rate compared to females was found during pupal development, which may cause the differences in weight loss (Fischer et al. 2004).

\subsubsection{Mechanistic basis of the temperature-size rule}

While the above evidence (sex- and populationspecific reaction norms) suggests that the temperaturesize rule may be affected by selection (see also Trotta et al. 2010), another open issue concerns the mechanistic basis of the temperature-size rule. How do such differences in body mass across temperatures come about? An analysis using Lycaena tityrus revealed a number of patterns (Karl \& Fischer 2008). The larger body size at the lower temperature was proximately due to a higher mass increment during late larval development. This pattern resulted from both behavioural and physiological mechanisms: i.e. a much increased food intake and a higher efficiency in converting ingested food into body matter, despite a lower assimilation (Karl \& Fischer 2008). The latter means that although a higher proportion of the food ingested was actually assimilated at a higher temperature, a relatively smaller fraction of the digested food could be converted into body matter. This is most likely related to higher metabolic losses at the higher temperature (Kingsolver \& Woods 1998, Renault et al. 2002). Such mechanisms, combined with temperature-induced changes at the cellular level, may explain the temperature-size rule, which, however, need further experimental testing.

\subsection{Genetic responses: altitudinal variation in life-history and stress resistance traits}

Due to the typically wide range of temperatures experienced in space and time, organisms are expected to show genetic adaptations to such variation in addition to the above plastic responses (e.g. Chown \& Klok 2003, Van Doorslaer \& Stoks 2005). Investigating geographic clines has become a key element in the study of (thermal) adaptive evolution (Sørensen et al. 2005, Sambucetti et al. 2006, Sarup et al. 2006). While the majority of previous studies has focussed on latitudinal clines (e.g. Addo-Bediako et al. 2000, Loeschcke et al. 2000, Van Doorslaer \& Stoks 2005), we compared populations of Lycaena tityrus from different altitudes (Karl et al. 2008a, 2009b,c, Karl \& Fischer 2009). Though high altitudes and latitudes share similarly extreme environmental conditions (Bubliy \& Loeschcke 2005, Sørensen et al. 2005), altitudinal changes occur over relatively small distances such that, in contrast to latitudinal variation, gene flow is likely to be much more important (Sarup et al. 2009). Nevertheless, our studies revealed a number of patterns. In describing these we will focus on differences between high- and low-altitude populations, although some of the traits considered were also investigated in mid-altitude populations, which mainly showed intermediate phenotypes (Karl et al. 2008a). We exclusively refer to macrolevel environmental variation here, while some other studies have also included micro-level variation (e.g. Kristensen et al. 2004).

\subsubsection{Developmental traits}

In common garden experiments, Lycaena tityrus populations from higher altitudes showed slower development (longer larval times accompanied by reduced larval growth rates) compared to those from lower altitudes (Karl et al. 2008a; Table 2). This is counterintuitive, as life-history theory generally predicts higher intrinsic growth rates at higher altitudes (or, more generally, in cooler environments), in order to compensate for seasonal time constraints and the overall lower temperatures (Abrams et al. 1996, Bubliy \& Loeschcke 2005, Iraeta et al. 2006). The reason for the deviation from the expected pattern in the case of L. tityrus is a change in voltinism: while high-altitude populations are monovoltine, low-altitude ones are bivoltine (Tolman \& Lewington 1998). Thus the time constraints imposed by fitting in an additional generation per year are more severe than those imposed by the cool alpine environment. The same pattern of reduced growth rates in mono- versus bivoltine populations has been described in Lycaena hippothoe (Fischer \& Fiedler 2002a) and other butterfly species (e.g. Aricia agestis; Burke et al. 2005). However, when comparing 2 monovoltine populations in L. hippothoe, the alpine population exhibited higher growth rates and concomitantly shorter development times than the low-altitude one, as expected (Fischer \& Fiedler 2002b).

Regarding body mass, in contrast, no differences across populations from different altitudes were found in Lycaena tityrus (Karl et al. 2008a). For 2 reasons 
Table 2. Lycaena sp. Relative differences in life-history and other traits across high- and low-altitude populations of copper butterflies. The putative (selective) forces responsible for the variation found are given in the last column. $\uparrow:$ increased; $\downarrow$ : decreased; =: equal; arrows in parentheses: trend; PGI: phosphoglucose isomerase; HSP: heat shock protein

\begin{tabular}{|lccll}
\hline \multirow{2}{*}{ Trait } & \multirow{2}{*}{ Altitude } & Selective force \\
& High & Low & \\
\hline Development time & $\uparrow$ & $\downarrow$ & Change in voltinism \\
Body size & $=$ & $=$ & Complex interactions \\
Thorax mass & $=$ & $=$ & Complex interactions \\
Body fat content & $\downarrow$ & $\uparrow$ & Unclear \\
Egg size & $\uparrow$ & $\downarrow$ & Temperature / season \\
& & & length \\
Wing size, wing aspect ratio, wing & $=$ & $=$ & Complex interactions \\
loading & & & \\
Flight performance at suboptimal & $\uparrow$ & $\downarrow$ & Temperature \\
temperature & & & \\
Adult life span & $\uparrow$ & $(\downarrow)$ & Food availability \\
Wing melanisation & $\uparrow$ & $\downarrow$ & Temperature \\
Pupal melanisation & $\uparrow$ & $\downarrow$ & Unclear \\
Cold stress resistance & $\uparrow$ & $\downarrow$ & Temperature \\
Frequency of cold stress resistant & $\uparrow$ & $\downarrow$ & Temperature \\
PGI genotype & & & \\
Heat stress resistance & $\downarrow$ & $\uparrow$ & Temperature \\
(Plasticity in) heat stress resistance & $\downarrow$ & $\uparrow$ & Temperature \\
Plasticity in HSP expression & $\downarrow$ & $\uparrow$ & Temperature \\
\hline
\end{tabular}

a higher body mass in high-altitude animals was expected: (1) because body size is typically larger in cooler environments (Bergmann size clines extended to ectotherms; Atkinson 1994, Angilletta \& Dunham 2003, but see Kingsolver et al. 2007), and (2) because the accelerated development in low-altitude populations should be associated with a smaller body size (cf. Fischer \& Fiedler 2002b, Fischer et al. 2004). Thus the lack of differentiation found here highlights the notion that associations between body size and environmental (temperature) variation are more complex than previously thought, and may range from positive to negative (Chown \& Klok 2003, Blanckenhorn \& Demont 2004, Iraeta et al. 2006, Cvetkoviç et al. 2009). Such diverging patterns presumably result from interactions between temperature, generation time, voltinism and season length, all of which affect insect body size (Blanckenhorn 1997, Chown \& Gaston 1999). In a related species (L. hippothoe) there was also no difference in body size across altitudes (Fischer \& Fiedler 2002b). Nevertheless, egg size was considerably larger in high-altitude compared to lowaltitude animals (Fischer \& Fiedler 2001e). Presumably, large egg size helps to reduce development time and withstand environmental stress, which should confer a fitness advantage in alpine environments, characterized by short season length and cool temperatures (Fischer \& Fiedler 2001e, cf. Fischer et al. 2003).

\subsubsection{Flight performance, adult mor- phology and adult life span}

In addition to the patterns described above, Lycaena tityrus shows altitudinal variation in flight performance (Karl et al. 2008a), a trait closely related to fitness in flying organisms (Barnes \& Laurie-Ahlberg 1986, Merckx et al. 2006). Specifically, animals from high altitudes showed increased flight durations when forced to fly at suboptimal temperatures compared to animals from low altitudes. Consequently, high-altitude butterflies will be able to fly and thereby to initiate e.g. feeding or mate location behaviour at fairly low temperatures, which should confer a fitness advantage in cool alpine environments (Karl et al. 2008a). Interestingly though, this difference in flight performance is not underpinned by any morphological differentiation in wing size and shape, wing aspect ratio, wing loading or thorax mass (Karl et al. 2008a), traits usually associated with variation in flight performance (e.g. Berwaerts et al. 2002, Van Dyck \& Wiklund 2002, Berwaerts \& Van Dyck 2004). Further, body fat content was higher in low- compared to high-altitude butterflies, rendering an association between fat content and flight performance unlikely (Karl et al. 2008a). Taken together, the evidence suggests that the altitudinal differentiation in flight performance in L. tityrus has a physiological rather than a morphological basis (see below).

Regarding adult life span, there was a tendency towards a higher longevity in high-altitude butterflies (Karl \& Fischer 2009). However, this increase in life span was largely restricted to beneficial feeding conditions, while under carbohydrate deprivation lowaltitude animals lived longer. Thus low-altitude butterflies do better under food stress, while the opposite is true under beneficial feeding conditions (Karl \& Fischer 2009). Generally, a reduced longevity (often with a concomitantly increased early fecundity) is expected for high-altitude populations due to hazardous environmental conditions (Lencioni 2004, Norry et al. 2006). The opposite trend found here is presumably related to nectar plant availability. While the flight period of the monovoltine high-altitude populations is very well synchronised with a period of high nectar flower abundance, bivoltine low-altitude butterflies, in particular in the (late) summer generation, may regularly be faced with a shortage of nectar plants (Karl \& Fischer 2009). 


\subsubsection{Wing and pupal melanisation: a case of thermal melanism?}

In Lycaena tityrus, high-altitude butterflies have substantially darker wings than low-altitude ones (Karl et al. 2009c), thus showing the expected pattern of darker phenotypes being associated with cooler environments. This pattern, indicating directional thermal selection of pigmentation, has been described in variety of insects (e.g. Ellers \& Boggs 2002, Espeland et al. 2007, Pool \& Aquadro 2007, Rajpurohit et al. 2008), and the associated thermal benefits, e.g. facilitating flight at suboptimal temperatures, are well established (e.g. Ellers \& Boggs 2004, Stoehr \& Goux 2008). More interestingly though, we found a parallel pattern in pupal melanisation, showing a strong increase with increasing altitude, in L. hippothoe and L. tityrus (Karl et al. 2009c). Why this should be so for an immobile stage is currently unclear. On the one hand, darker pupae (as well as artificially melanised pupae) reached higher body temperatures under laboratory and field conditions (Karl et al. 2009c). While this may in principle speed up development, absolute temperature differences were relatively small, such that any reduction in development time will also be small. It is moreover unclear for how long pupae are actually exposed to direct sunlight. Because a higher developmental temperature increased rather than decreased pupal melanisation, temperature may not be the principle selective agent driving variation in pupal melanisation across altitudes (Karl et al. 2009c). Consequently, alternative hypotheses such as cryptic coloration, disease resistance and, in particular, protection from UV radiation need to be addressed (Gunn 1998, Gvozdik 1999, Wilson et al. 2001).

\subsubsection{Temperature stress resistance}

To test for differences in temperature stress resistance across altitudes, 2 well-established indicators of climatic adaptation, namely chill-coma recovery and heat knockdown time, were used (cf. Hallas et al. 2002, Hoffmann et al. 2002, David et al. 2003, Castañeda et al. 2005). As a result, high-altitude butterflies showed increased cold stress resistance but reduced heat stress resistance relative to low-altitude butterflies, suggesting directional thermal selection on stress resistance traits (Karl et al. 2008a; Table 2). While the former reflects more frequent exposure to cold stress, the latter reflects rarer exposure to heat stress in high altitudes and vice versa. Similar clinal patterns have been found in a number of other organisms (e.g. Hallas et al. 2002, Hoffmann et al. 2002, Castañeda et al. 2005, Hoffmann et al. 2005, Collinge et al. 2006). Such varia- tion in stress resistance might be associated with different thermal thresholds, allowing earlier activity in the morning, later activity in the evening and generally higher levels of activity under colder conditions (Gibert et al. 2001, Watt et al. 2003, Haag et al. 2005).

A parallel pattern was induced using temperature manipulations, with exposure to a lower temperature increasing cold stress resistance and decreasing heat stress resistance and vice versa (see above; Karl et al. 2008a). However, while the plastic response in cold stress resistance was uniform across populations from different altitudes (no genotype-environment interaction), low-altitude butterflies showed a much stronger response to different temperatures in heat stress tolerance compared to high-altitude butterflies (genotypeenvironment interaction; Karl et al. 2008a). Specifically, heat stress resistance in low-altitude individuals was much increased at a higher compared to a lower ambient temperature (Fig. 3). This accelerated plasticity may help low-altitude butterflies to deal with occasionally occurring spells of heat during summer, while the plastic response in high-altitude butterflies (normally not facing heat stress) was very weak (Karl et al. 2008a).

This pattern is echoed by differences in the expression of stress-inducible heat shock proteins (HSPs), with high-altitude butterflies showing a very weak response to a higher ambient temperature, while lowaltitude ones showed a substantial increase in HSP expression (Karl et al. 2009a; Fig. 3). The parallel pattern suggests that population-specific differences in the heat shock response may mechanistically underlie differences in heat stress resistance (Karl et al. 2008a, 2009a, but see e.g. Bahrndorff et al. 2010, this Special). In any case, the heat shock response, with HSPs functioning as molecular chaperones participating in protein folding and unfolding, is considered an essential mechanism for coping with unfavourable (thermal) conditions in ectothermic organisms (Sørensen et al. 2003, Dahlhoff 2004, Dahlhoff \& Rank 2007). Whether the reduced plasticity in heat tolerance and HSP expression found in Lycaena tityrus high-altitude populations is a common feature among cold-adapted species and populations, and whether this may potentially interfere with their long-term prospects facing global warming, deserves further investigation.

\subsubsection{Genetic make-up of thermal adaptation in Lycaena tityrus}

Facing rapid human-induced global warming, the mechanistic basis of thermal adaptation is an essential issue (see Section 1). To get a handle on the genetic mechanisms underlying thermal adaptation in Lycaena 

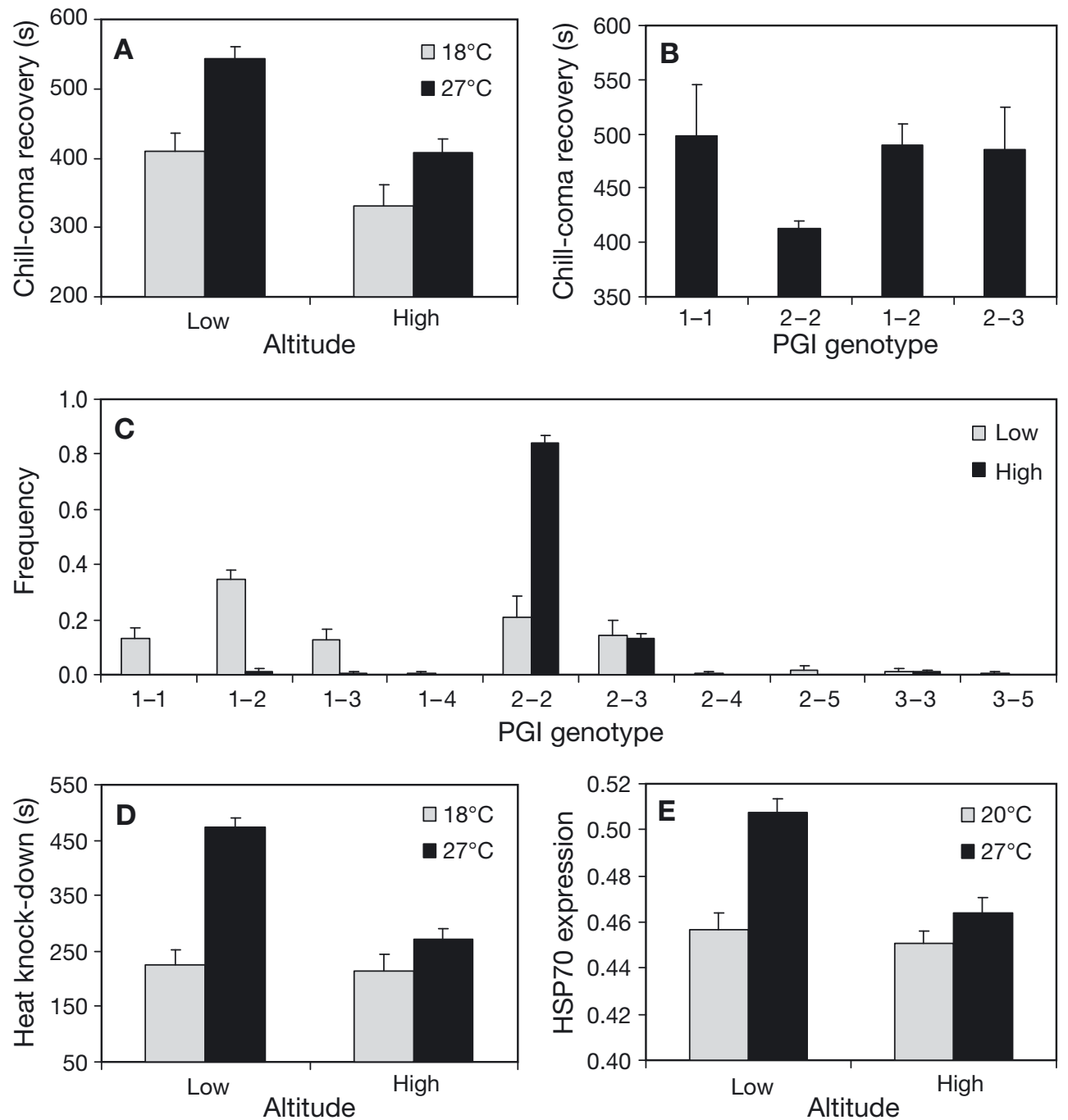

Fig. 3. Lycaena tityrus. Stress resistance traits, heat shock protein (HSP) expression and phosphoglucose isomerase (PGI) genotype frequencies (mean $\pm \mathrm{SE}$ ) in the copper butterfly. Chill coma recovery time in relation to (A) altitude and temperature and (B) PGI genotype; (C) PGI genotype frequency in relation to altitude; (D) heat knockdown time and (E) HSP expression, in relation to altitude and temperature (based on data published in Karl et al. 2008a,b, 2009a,b)

tityrus, we conducted a population genetic (allozyme) analysis based on 15 enzyme systems representing 18 loci. Allozymes are thought to be under selection, and their functional roles are well characterised (Berry \& Kreitman 1993, Eanes 1999, Storz \& Nachman 2003, Watt et al. 2003, Hanski \& Saccheri 2006). L. tityrus exhibits a remarkable genetic differentiation into an alpine (high-altitude) and a non-alpine (low-altitude) cluster (Karl et al. 2009b). This geographic differentiation is primarily caused by variation at a single locus, PGI, a key glycolytic enzyme at the central point of all ATP-based energy supplies, which has been suggested to be under thermal selection before (e.g. Watt 1994, Dahlhoff \& Rank 2000, 2007, Neargarder et al. 2003, McMillan et al. 2005, Rank et al. 2007). In all alpine populations, a single homozygote genotype (PGI-2-2) was dominant (frequencies $>84 \%$ ), while low-altitude populations showed much higher variation with many heterozygotes (Karl et al. 2009b). The genotype dominating in high altitudes showed the highest cold stress resistance, as evidenced by an experiment comparing PGI genotypes from a single low-altitude population (Karl et al. 2008b; Fig. 3). Consequently, both population genetic analysis and direct experimental evidence suggest that PGI is under thermal selection in $L$. tityrus, and that this locus may well cause the population-specific differences in cold stress resistance (Karl et al. 2008b, 2009b).

In Lycaena tityrus, PGI not only affects cold stress resistance, but additionally an array of life-history traits such as larval development time and pupal mass (Karl et al. 2008b, 2010). Consequently, PGI can be considered a gene of large and pleiotropic effects (see also Orsini et al. 2009, Klemme \& Hanski 2009). In another 
insect, the leaf beetle Chrysomelia aeneicollis, variation in HSP70 expression, temperature stress resistance, running speed, survival and fecundity were all related to directional changes in PGI allele frequencies (Dahlhoff \& Rank 2000, 2007, Rank \& Dahlhoff 2002, Neargarder et al. 2003, McMillan et al. 2005, Rank et al. 2007). Allelic variation at PGI may even affect population dynamics through effects on dispersal ability (Haag et al. 2005, Niitepold et al. 2009). To sum up, although other loci also contribute to thermal adaptation (Berry \& Kreitman 1993, McKenzie et al. 1994, Piccino et al. 2004, Huestis \& Marshall 2006), PGI seems to be one of the major players.

In contrast to cold stress resistance and life-history traits (see above), heat stress resistance was not affected by PGI genotype (Karl et al. 2008b), suggesting that the mechanisms underlying increased cold and heat tolerance are at least partly uncoupled (Klok \& Chown 2003, Sørensen et al. 2005). Additionally, there was no association between PGI genotype and flight performance at suboptimal temperatures in Lycaena tityrus (Karl et al. 2010). Based on the differences in flight performance and PGI allele frequencies across altitudes in L. tityrus (see above, and Section 3.2.2.), such a link was expected, in particular because in another butterfly PGI has been identified as a candidate locus affecting flight metabolic rate (Haag et al. 2005, Saastamoinen 2007, Saastamoinen et al. 2009, Orsini et al. 2009). Why this is not the case in L. tityrus needs to be explored in further detail.

\section{CONCLUSIONS}

In the copper butterflies studied, manipulating developmental temperature as well as comparing populations across altitudes yielded divergent patterns in numerous traits. Regarding temperature-induced plasticity, however, the adaptive significance of much of the variation found is still largely unclear (Table 1). This applies, for example, to variation in body size, total food consumption, the efficiency of converting digested food into body matter (the latter two enabling larger body size at lower temperatures), body fat and protein content, and pupal melanisation across temperatures. However, based on our results and those from other studies we can pose testable hypotheses regarding some of the traits. For instance, the temperature-size rule may result from the benefits of reproducing early at higher temperatures, indicating potential for extra generations (compound interest hypothesis; Fischer \& Fiedler 2002b), while increased pupal melanisation at higher temperatures may serve as a means of UV protection (Karl et al. 2009c). Variation in other temperature-dependent traits such as development time, daily food consumption and assimilation is due to physiological constraints. Differences in developmental pathways (diapause induction, number of larval instars), on the other hand, are closely related to changes in voltinism, with higher temperatures enabling production of additional generations due to rapid development. Thus only variation in cold and heat stress resistance seems to result from thermal adaptation per se, with heat resistance increasing at higher temperatures and cold resistance increasing at cooler temperatures, reflecting adaptive phenotypic plasticity (Zeilstra \& Fischer 2005, Karl et al. 2008a).

Similarly, much of the variation across copper butterfly populations from different altitudes was not directly related to thermal adaptation (Table 2). The clearest evidence comes from temperature stress resistance and putatively associated mechanisms, with highaltitude populations showing reduced heat but increased cold resistance compared to low-altitude populations (Karl et al. 2008a). Apart from that, cool alpine environments select for increased wing melanisation and increased flight performance at suboptimal temperatures, both indicating that flight performance is under strong selection in these butterflies (Karl et al. 2008a). However, many other traits such as development time, body size and adult life span did not seem to be affected in the first place by thermal adaptation. Our results suggest that while temperature is an important ecological factor, other factors contributing to clinal variation should not be neglected. In particular, seasonal time constraints and associated windows of opportunity seem to exert strong selective pressures on these temperate zone insects. Our results on both plastic responses and clinal variation caution against overstressing the importance of temperature for shaping animal life histories, with thermal adaptation being most obvious in traits directly related to stress resistance.

Acknowledgements. The work reviewed here was facilitated by grants from the Friedrich-Ebert Foundation and the German Research Council (DFG grant no. Fi 846/1) to K.F. K.F. acknowledges financial support from the European Science Foundation through the networking programs ConGen and ThermAdapt to join the Białowieża Workshop.

\section{LITERATURE CITED}

Abrams PA, Leimar O, Nylin S, Wiklund C (1996) The effect of flexible growth rates on optimal sizes and development times in a seasonal environment. Am Nat 147:381-395

Addo-Bediako A, Chown SL, Gaston KJ (2000) Thermal tolerance, climatic variability and latitude. Proc R Soc Lond B $267: 739-745$

Amarillo-Suárez AR, Fox CW (2006) Population differences in host use by a seed-beetle: local adaptation, phenotypic plasticity and maternal effects. Oecologia 150:247-258 
Anderson AR, Collinge JE, Hoffmann AA, Kellett M, McKechnie SW (2003) Thermal tolerance trade-offs associated with the right arm of chromosome 3 and marked by the hsr-omega gene in Drosophila melanogaster. Heredity 90:195-202

Angilletta MJ Jr, Dunham A (2003) The temperature-size rule in ectotherms: simple evolutionary explanations may not be general. Am Nat 162:332-342

Angilletta MJ Jr, Niewiarowski PH, Navas CA (2002) The evolution of thermal physiology in ectotherms. J Therm Biol 27:249-268

Angilletta MJ Jr, Steury TD, Sears MW (2004) Temperature, growth rate, and body size in ectotherms: fitting pieces of a life-history puzzle. Integr Comp Biol 44:498-509

Atkinson D (1994) Temperature and organism size-a biological law for ectotherms. Adv Ecol Res 25:1-58

Atkinson D, Morley SA, Hughes RN (2006) From cells to colonies: At what levels of body organization does the 'temperature-size rule' apply? Evol Dev 8:202-214

Bahrndorff S, Maien J, Loeschcke V, Ellers J (2009) Dynamics of heat-induced thermal stress resistance and Hsp70expression in the springtail, Orchesella cincta. Funct Ecol 23:233-239

Bahrndorff S, Mariën J, Loeschcke V, Ellers J (2010) Genetic variation in heat resistance and HSP70 expression in inbred isofemale lines of the springtail Orchesella cincta. Clim Res 43:41-47

Barnes PT, Laurie-Ahlberg CC (1986) Genetic variability of flight metabolism in Drosophila melanogaster. III. Effects of Gpdh isoenzymes and environmental temperature on power output. Genetics 112:267-294

Bauerfeind SS, Theisen A, Fischer K (2009) Patch occupancy in the endangered butterfly Lycaena helle in a fragmented landscape: effects of habitat quality, patch size and isolation. J Insect Conserv 13:271-277

Berry A, Kreitman M (1993) Molecular analysis of an allozyme cline-alcohol-dehydrogenase in Drosophila melanogaster on the east coast of North America. Genetics 134:869-893

> Berwaerts K, Van Dyck H (2004) Take-off performance under optimal and suboptimal thermal conditions in the butterfly Pararge aegeria. Oecologia 141:536-545

Berwaerts K, Van Dyck H, Aerts P (2002) Does flight morphology relate to flight performance? An experimental test with the butterfly Pararge aegeria. Funct Ecol 16:484-491

Bijlsma R, Loeschcke V (2005) Environmental stress, adaptation and evolution: an overview. J Evol Biol 18:744-749

Blanckenhorn WU (1997) Altitudinal life history variation in the dung flies Scathophaga stercoraria and Sepsis cynipsea. Oecologia 109:342-352

Blanckenhorn WU, Demont M (2004) Bergmann and converse Bergmann latitudinal clines in arthropods: two ends of a continuum? Integr Comp Biol 44:413-424

Bolker JA (1995) Model systems in developmental biology. Bioessays 17:451-455

> Bradshaw AD (1965) Evolutionary significance of phenotypic plasticity in plants. Adv Genet 13:115-155

Bridges CA (1988) Catalogue of Lycaenidae and Riodinidae (Lepidoptera: Rhopalocera). C. A. Bridges, Urbana, IL

Brower LP, Williams EH, Slayback DA, Fink LS and others (2009) Oyamel fir forest trunks provide thermal advantages for overwintering monarch butterflies in Mexico. Insect Conserv Divers 2:163-175

Bubliy OA, Loeschcke V (2005) Variation of life-history and morphometrical traits in Drosophila buzzatii and Drosophila simulans collected along an altitudinal gradient from a Canary island. Biol J Linn Soc 84:119-136

Burke S, Pullin AS, Wislon RJ, Thomas CD (2005) Selection for discontinuous life-history traits along a continuous thermal gradient in the butterfly Aricia agestis. Ecol Entomol 30:613-619

Cabanita R, Atkinson D (2006) Seasonal time constraints do not explain exceptions to the temperature size rule in ectotherms. Oikos 114:431-440

Castañeda LE, Lardies MA, Bozinovic F (2005) Interpopulational variation in recovery time from chill coma along a geographic gradient: a study in the common woodlouse, Porcellio laevis. J Insect Physiol 51:1346-1351

> Chown SL, Gaston KJ (1999) Exploring links between physiology and ecology at macroscales: the role of respiratory metabolism in insects. Biol Rev Camb Philos Soc 74: $87-120$

Chown SL, Klok C (2003) Altitudinal body size clines: latitudinal effects associated with changing seasonality. Ecography 26:445-455

Chown SL, Hoffmann AA, Kristensen TN, Angilletta MJ Jr, Stenseth NC, Pertoldi C (2010) Adapting to climate change: a perspective from evolutionary physiology. Clim Res 43:3-15

Clarke A (2003) Costs and consequences of evolutionary temperature adaptation. Trends Ecol Evol 18:573-581

Clarke A (2006) Temperature and the metabolic theory of ecology. Funct Ecol 20:405-412

Clench HK (1966) Behavioral thermoregulation in butterflies. Ecology 47:1021-1034

Collinge JE, Hoffmann AA, McKechnie SW (2006) Altitudinal patterns for latitudinally varying traits and polymorphic markers in Drosophila melanogaster from eastern Australia. J Evol Biol 19:473?482

Cvetković D, Tomašević N, Ficetola GF, Crnobrnja-Isailović J, Miaud C (2009) Bergmann's rule in amphibians: combining demographic and ecological parameters to explain body size variation among populations in the common toad Bufo bufo. J Zool Syst Evol Res 47:171-180

Dahlhoff EP (2004) Biochemical indicators of stress and metabolism: applications for marine ecological studies. Annu Rev Physiol 66:183-207

> Dahlhoff EP, Rank NE (2000) Functional and physiological consequences of genetic variation at phosphoglucose isomerase: heat shock protein expression is related to enzyme genotype in a montane beetle. Proc Natl Acad Sci USA 97:10056-10061

> Dahlhoff EP, Rank NE (2007) The role of stress proteins in responses of a montane willow leaf beetle to environmental temperature variation. J Biosci 32:477-488

> David JR, Gibert P, Moreteau B, Gilchrist GW, Huey RB (2003) The fly that came in from the cold: geographic variation of recovery time from low-temperature exposure in Drosophila subobscura. Funct Ecol 17:425-430

de Jong MA, Kesbeke FMNH, Brakefield PM, Zwaan BJ (2010) Geographic variation in thermal plasticity of life history and wing pattern in Bicyclus anynana. Clim Res 43:91-102

> Dockx C, Brower LP, Wassenaar LI, Hobson KA (2004) Do North American monarch butterflies travel to Cuba? Stable isotope and chemical tracer techniques. Ecol Appl 14:1106-1114

Douwes P (1975) Distribution of a population of the butterfly Heodes virgaureae. Oikos 26:332-340

> Douwes P (1976) Activity in Heodes virgaureae in relation to air temperature, solar radiation and time of day. Oecologia 22:287-298

Duffey E (1977) The re-establishment of the large copper butterfly Lycaena dispar Haw. batavus Obth. at Woodwalton Fen National Nature Reserve, Cambridgeshire. Biol Con- 
serv 12:143-158

Eanes WF (1999) Analysis of selection on enzyme polymorphisms. Annu Rev Ecol Syst 30:301-326

Ebert G, Rennwald E (1991) Die Schmetterlinge BadenWürttembergs, Vol 2. Ulmer, Stuttgart

Ellers J, Boggs CL (2002) The evolution of wing color in Colias butterflies: heritability, sex linkage, and population divergence. Evolution 56:836-840

Ellers J, Boggs CL (2004) Functional ecological implications of intraspecific differences in wing melanisation in Colias butterflies. Biol J Linn Soc 82:79-87

Endo K, Kamata Y (1985) Hormonal control of seasonalmorph determination in the small copper butterfly, Lycaena phlaeas daimio Seitz. J Insect Physiol 31:701-706

Endo K, Shibata M (1987) A circadian aspect of the photoperiodic time-measurement on the basis of the larvalecdysis rhythm in the small copper butterfly, Lycaena phlaeas daimio Seitz. Zool Sci 4:683-692

Endo K, Maruyama Y, Sasaki K (1985) Environmental factors controlling seasonal morph determination in the small copper butterfly, Lycaena phlaeas daimio Seitz. J Insect Physiol 31:525-532

Espeland M, Aagaard K, Balstad T, Hindar K (2007) Ecomorphological and genetic divergence between lowland and montane forms of the Pieris napi species complex (Pieridae, Lepidoptera). Biol J Linn Soc 92:727-745

- Fagerström T, Wiklund C (1982) Why do males emerge before females? Protandry as a mating strategy in male and female butterflies. Oecologia 52:164-166

> Finger A, Schmitt T, Zachos FE, Meyer M, Assmann T, Habel JC (2009) The genetic status of the violet copper Lycaena helle: a relict of the cold past in times of global warming. Ecography 32:382-390

Fischer K, Fiedler K (2000a) Response of the copper butterfly Lycaena tityrus to increased leaf nitrogen in natural foodplants: evidence against the nitrogen limitation hypothesis. Oecologia 124:235-241

Fischer K, Fiedler K (2000b) Sex-related differences in reaction norms in the butterfly Lycaena tityrus (Lepidoptera: Lycaenidae). Oikos 90:372-380

> Fischer K, Fiedler K (2001a) Resource-based territoriality in the butterfly Lycaena hippothoe and environmentally induced behavioural shifts. Anim Behav 61:723-732

Fischer K, Fiedler K (2001b) Dimorphic growth patterns and sex-specific reaction norms in the butterfly Lycaena hippothoe sumadiensis. J Evol Biol 14:210-218

Fischer K, Fiedler K (2001c) Effects of larval starvation on adult life-history traits in the butterfly Lycaena tityrus (Lepidoptera: Lycaenidae). Entomol Gen 25:249-254

Fischer K, Fiedler K (2001d) Sexual differences in life-history traits in the butterfly Lycaena tityrus: a comparison between direct and diapause development. Entomol Exp Appl 100:325-330

Fischer K, Fiedler K (2001e) Egg weight variation in the butterfly Lycaena hippothoe: more small or fewer large eggs? Popul Ecol 43:105-109

- Fischer K, Fiedler K (2002a) Life-history plasticity in the butterfly Lycaena hippothoe: local adaptations and trade-offs. Biol J Linn Soc 75:173-185

Fischer K, Fiedler K (2002b) Reaction norms for age and size at maturity in response to temperature: a test of the compound interest hypothesis. Evol Ecol 16:333-349

Fischer K, Beinlich B, Plachter H (1999) Population structure, mobility and habitat preferences of the violet copper Lycaena helle (Lepidoptera: Lycaenidae): implications for conservation. J Insect Conserv 3:43-52

Fischer K, Brakefield PM, Zwaan BJ (2003) Plasticity in but- terfly egg size: why larger offspring at lower temperatures? Ecology 84:3138-3147

Fischer K, Zeilstra I, Hetz SK, Fiedler K (2004) Physiological costs of growing fast: Does accelerated growth reduce pay-off in adult fitness? Evol Ecol 14:343-353

Flannery CM (1997) Models in biology. Am Biol Teach 59: $244-248$

Geister TL, Fischer K (2007) Testing the beneficial acclimation hypothesis: temperature effects on mating success in a butterfly. Behav Ecol 18:658-664

> Gibert P, Moreteau B, Petavy G, Karan D, David JR (2001) Chill coma tolerance: a major climatic adaptation among Drosophila species. Evolution 55:1063-1068

Gunn A (1998) The determination of larval phase coloration in the African armyworm, Spodoptera exempta and its consequences for thermoregulation and protection from UV light. Entomol Exp Appl 86:125-133

Gvozdik L (1999) Colour polymorphism in a population of the common lizard, Zootoca vivipara (Squamata: Lacertidae). Folia Zool 48:131-136

> Haag CR, Saastamoinen M, Marden JH, Hanski I (2005) A candidate locus for variation in dispersal rate in a butterfly metapopulation. Proc R Soc Lond B 272:2449-2456

Hallas R, Schiffer M, Hoffmann AA (2002) Clinal variation in Drosophila serrata for stress resistance and body size. Genet Res 79:141-148

> Hanski I, Saccheri I (2006) Molecular-level variation affects population growth in a butterfly metapopulation. PLoS Biol 4:e129

Helmuth B (2002) How do we measure the environment? Linking intertidal thermal physiology and ecology through biophysics. Integr Comp Biol 42:837-845

Hitch AT, Leberg PL (2007) Breeding distributions of North American bird species moving north as a result of climate change. Conserv Biol 21:534-539

> Hoffmann AA, Anderson A, Hallas R (2002) Opposing clines for high and low temperature resistance in Drosophila melanogaster. Ecol Lett 5:614-618

> Hoffmann AA, Sørensen JG, Loeschcke V (2003) Adaptation of Drosophila to temperature extremes: bringing together quantitative and molecular approaches. J Therm Biol 28: $175-216$

> Hoffmann AA, Shirriffs J, Scott M (2005) Relative importance of plastic vs. genetic factors in adaptive differentiation: geographical variation for stress resistance in Drosophila melanogaster from Eastern Australia. Funct Ecol 19: $222-227$

- Honek A (1993) Intraspecific variation in body size and fecundity in insects: a general relationship. Oikos 66:483-492

> Huestis DL, Marshall JL (2006) Is natural selection a plausible explanation for the distribution of Idh-1 alleles in the cricket Allonemobius socius? Ecol Entomol 31:91-98

Iraeta P, Monasterio C, Salvador A, Díaz JA (2006) Mediterranean hatchling lizards grow faster at higher altitude: a reciprocal transplant experiment. Funct Ecol 20:865-872

Johnston IA, Bennett AF (1996) Animals and temperature. Cambridge University Press, Cambridge

Karl I, Fischer K (2008) Why get big in the cold? Towards a solution of a life-history puzzle. Oecologia 155:215-225

Karl I, Fischer K (2009) Altitudinal and environmental variation in lifespan in the copper butterfly Lycaena tityrus. Funct Ecol 23:1132-1138

Karl I, Janowitz SA, Fischer K (2008a) Altitudinal life-history variation and thermal adaptation in the copper butterfly Lycaena tityrus. Oikos 117:778-788

- Karl I, Schmitt T, Fischer K (2008b) Phosphoglucose isomerase genotype affects life-history traits and cold stress 
resistance in a copper butterfly. Funct Ecol 22:887-894

Karl I, Sørensen JG, Loeschcke V, Fischer K (2009a) HSP70 expression in the copper butterfly Lycaena tityrus across altitudes and temperatures. J Evol Biol 22:172-178

Karl I, Schmitt T, Fischer K (2009b) Genetic differentiation between alpine and lowland populations of a butterfly is related to PGI enzyme genotype. Ecography 32:488-496

Karl I, Geister TL, Fischer K (2009c) Intraspecific variation in wing and pupal melanisation in copper butterflies (Lepidoptera: Lycaenidae). Biol J Linn Soc 98:301-312

Karl I, Hoffmann KH, Fischer K (2010) Food stress sensitivity and flight performance across phosphoglucose isomerase enzyme genotypes in a copper butterfly. Popul Ecol 52: 307-315

Kelty JD, Lee RE (1999) Induction of rapid cold hardening by ecologically relevant cooling rates in Drosophila melanogaster. J Insect Physiol 45:719-726

Kelty JD, Lee RE (2001) Rapid cold-hardening of Drosophila melanogaster (Diptera: Drosophilidae) during ecologically based thermoperiodic cycles. J Exp Biol 204:1659-1666

Kingsolver JG, Watt WB (1984) Mechanistic constraints and optimality models: thermoregulatory strategies in Colias butterflies. Ecology 65:1835-1839

Kingsolver JG, Woods HA (1998) Interactions of temperature and dietary protein concentration in growth and feeding of Manduca sexta caterpillars. Physiol Entomol 23:354-359

Kingsolver JG, Massie KR, Ragland GJ, Smith MH (2007) Rapid population divergence in thermal reaction norms for an invading species: breaking the temperature-size rule. J Evol Biol 20:892-900

Kjærsgaard A, Faurby S, Krag K, Loeschcke V, Pertoldi C (2010) Temperature-maternal age interactions on wing traits in outbred Drosophila mercatorum. Clim Res 43: 49-56

Klemme I, Hanski I (2009) Heritability of and strong single gene (Pgi) effects on life-history traits in the Glanville fritillary butterfly. J Evol Biol 22:1944-1953

Klok CJ, Chown SL (2003) Resistance to temperature extremes in sub-Antarctic weevils: interspecific variation, population differentiation and acclimation. Biol J Linn Soc 78: 401-414

Kristensen TN, Pertoldi C, Pedersen LD, Andersen DH, Bach LA, Loeschcke V (2004) The increase of fluctuating asymmetry in a monoclonal strain of collembolans after chemical exposure: discussing a new method for estimating the environmental variance. Ecol Indic 4:73-81

> Lee RE, Chen CP, Denlinger DL (1987) A rapid coldhardening process in insects. Science 238:1415-1417

Lencioni V (2004) Survival strategies of freshwater insects in cold environments. J Limnol 63:45-55

Loeschcke V, Bundgaard J, Barker JSF (2000) Variation in body size and life history traits in Drosophila aldrichi and D. buzzatii from a latitudinal cline in eastern Australia. Heredity 85:423-433

- Marais E, Terblanche JS, Chown SL (2009) Life stage-related differences in hardening and acclimation of thermal tolerance traits in the kelp fly, Paratora dreuxi (Diptera, Helcomyzidae). J Insect Physiol 55:336-343

Martin LA, Pullin AS (2004) Host-plant specialization and habitat restriction in an endangered insect, Lycaena dispar batavus (Lepidoptera: Lycaenidae). I. Larval feeding and oviposition preferences. Eur J Entomol 101:51-56

McKenzie JA, McKechnie SW, Batterham P (1994) Perturbation of gene frequencies in a natural population of Drosophila melanogaster: evidence for selection at the ADH locus. Genetica 92:187-196

McMillan D, Fearnley SL, Rank NE, Dahlhoff EP (2005) Nat- ural temperature variation affects larval survival, development and Hsp70 expression in a leaf beetle. Funct Ecol 19:844-852

> Merckx T, Karlsson B, Van Dyck H (2006) Sex- and landscape-related differences in flight ability under suboptimal temperatures in a woodland butterfly. Funct Ecol 20:436-441

Mousseau TA, Dingle H (1991) Maternal effects in insect life histories. Annu Rev Entomol 36:511-534

Mousseau TA, Fox CW (1998) The adaptive significance of maternal effects. Trends Ecol Evol 13:403-407

Neargarder G, Dahlhoff EP, Rank NE (2003) Variation in thermal tolerance is linked to phosphoglucose isomerase genotype in a montane leaf beetle. Funct Ecol 17:213-221

Nicholls CN, Pullin AS (2000) A comparison of larval survivorship in wild and introduced populations of the large copper butterfly (Lycaena dispar batavus). Biol Conserv 93: 349-358

Niitepold K, Smith AD, Osborne JL, Reynolds DR and others (2009) Flight metabolic rate and Pgi genotype influence butterfly dispersal rate in the field. Ecology 90:2223-2232

- Norry FM, Sambucetti P, Scannapieco AC, Loeschcke V (2006) Altitudinal patterns for longevity, fecundity and senescence in Drosophila buzzatii. Genetica 128:81-93

Orsini L, Wheat CW, Haag CR, Kvist J, Frilander MJ, Hanski I (2009) Fitness differences associated with Pgi SNP genotypes in the Glanville fritillary butterfly (Melitaea cinxia). J Evol Biol 22:367-375

> Parmesan C, Ryrholm N, Stefanescu C, Hill JK and others (1999) Poleward shifts in geographical range of butterfly species associated with regional warming. Nature 399: 579-583

Partridge L, Coyne JA (1997) Bergmann's rule in ectotherms: is it adaptive? Evolution 51:632-635

Piccino P, Viard F, Sarradin PM, Le Bris N, Le Guen D, Jollivet D (2004) Thermal selection of PGM allozymes in newly founded populations of the thermotolerant vent polychaete Alvinella pompejana. Proc R Soc Lond B 271:2351-2359

Pigliucci M (2001) Phenotypic plasticity: beyond nature and nurture. John Hopkins University Press, Baltimore, MD

> Pool JE, Aquadro CF (2007) The genetic basis of adaptive pigmentation variation in Drosophila melanogaster. Mol Ecol 16:2844-2851

Rajpurohit S, Parkash R, Ramniwas S, Singh S (2008) Variations in body melanisation, ovariole number and fecundity in highland and lowland populations of Drosophila melanogaster from the Indian subcontinent. Insect Sci 15: $553-561$

Rank NE, Dahlhoff EP (2002) Allele frequency shifts in response to climate change and physiological consequences of allozyme variation in a montane insect. Evolution 56: 2278-2289

Rank NE, Bruce DA, McMillan DM, Barklay C, Dahlhoff EP (2007) Phosphoglucose isomerase genotype affects running speed and heat shock protein expression after exposure to extreme temperatures in a montane willow beetle. J Exp Biol 210:750-764

Renault D, Hervant F, Vernon P (2002) Comparative study of the metabolic responses during food shortage and subsequent recovery at different temperatures in the adult lesser mealworm, Alphitobius diaperinus (Coleoptera: Tenebrionidae). Physiol Entomol 27:291-301

> Rezende EL, Balanyà J, Rodríguez-Trelles F, Rego C, Fragata I, Mato M (2010) Climate change and chromosomal inversions in Drosophila subobscura. Clim Res 43:103-114

Roff DA (2002) The evolution of life histories: theory and analysis. Chapman \& Hall, New York 
Saastamoinen M (2007) Life-history, genotypic, and environmental correlates of clutch size in the Glanville fritillary butterfly. Ecol Entomol 32:235-242

Saastamoinen M, Ikonen S, Hanski I (2009) Significant effects of Pgi genotype and body reserves on lifespan in the Glanville fritillary butterfly. Proc R Soc Lond B 276: 1313-1322

Sambucetti P, Loeschcke V, Norry FM (2006) Developmental time and size-related traits in Drosophila buzzattii along an altitudinal gradient from Argentina. Hereditas 143:77-83

Sarup P, Sørensen JG, Dimitrov K, Barker JSF, Loeschcke V (2006) Climatic adaptation of Drosophila buzzatii populations in southeast Australia. Heredity 96:479-486

Sarup P, Frydenberg J, Loeschcke V (2009) Local adaptation of stress related traits in Drosophila buzzatii and Drosophila simulans in spite of high gene flow. J Evol Biol 22: 1111-1122

Scharf I, Bauerfeind SS, Blanckenhorn WU, Schäfer MA (2010) Effects of maternal and offspring environmental conditions on growth, development and diapause in latitudinal yellow dung fly populations. Clim Res 43:115-125

Sejerkilde M, Sørensen JG, Loeschcke V (2003) Effects of cold- and heat hardening on thermal resistance and Hsp70 expression in Drosophila melanogaster. J Insect Physiol 49:719-726

Sinclair BJ, Vernon P, Klok CJ, Chown SL (2003) Insects at low temperatures: an ecological perspective. Trends Ecol Evol 18:257-262

Sørensen JG, Kristensen TN, Loeschcke V (2003) The evolutionary and ecological role of heat shock proteins. Ecol Lett 6:1025-1037

Sørensen JG, Norry FM, Scannapeico AC, Loeschcke V (2005) Altitudinal variation for stress resistance traits and thermal adaptation in adult Drosophila buzzatii from the New World. J Evol Biol 18:829-837

Steigenga MJ, Fischer K (2007) Within- and betweengeneration effects of temperature on life-history traits in a butterfly. J Therm Biol 32:396-405

Stoehr AM, Goux H (2008) Seasonal phenotypic plasticity of wing melanisation in the cabbage white butterfly, Pieris rapae L. (Lepidoptera: Pieridae). Ecol Entomol 33:137-143

Storz JF, Nachman MW (2003) Natural selection on protein polymorphism in the rodent genus Peromyscus: evidence from interlocus contrasts. Evolution 57:2628-2635

Tolman T, Lewington R (1998) Die Tagfalter Europas und Nordwestafrikas. Franckh-Kosmos, Stuttgart

Trotta V, Pertoldi C, Rudoy A, Manenti T, Cavicchi S, Guerra D (2010) Thermal plasticity of wing size and shape in Drosophila melanogaster, D. simulans and their hybrids.
Clim Res 43:71-79

Turlure C, Van Dyck H (2009) On the consequences of aggressive mate-locating behaviour and micro-climate for female host plant use in the butterfly Lycaena hippothoe. Behav Ecol Sociobiol 63:1581-1591

> Van Doorslaer W, Stoks R (2005) Growth rate plasticity to temperature in two damselfly species differing in latitude: contributions of behaviour and physiology. Oikos 111: 599-605

$>$ Van Doorslaer W, Stoks R, Swillen I, Feuchtmayr H, Atkinson D, Moss B, De Meester L (2010) Experimental thermal microevolution in community-embedded Daphnia populations. Clim Res 43:81-89

> Van Dyck H, Matthysen E (1998) Thermoregulatory differences between phenotypes in the speckled wood butterfly: hot perchers and cold patrollers? Oecologia 114: 326-334

- Van Dyck H, Wiklund C (2002) Seasonal butterfly design: morphological plasticity among three developmental pathways relative to sex, flight and thermoregulation. J Evol Biol 15:216-225

Van Swaay CAM, Warren MS (1999) Red Data Book of European butterflies (Rhopalocera). Nature and Environment No. 99, Council of Europe Publishing, Strasbourg

> Walters RJ, Hassall M (2006) The temperature-size rule in ectotherms: May a general explanation exist after all? Am Nat 167:510-523

Watt WB (1994) Allozymes in evolutionary genetics: Selfimposed burden or extraordinary tool? Genetics 136: $11-16$

- Watt WB, Wheat CW, Meyer EH, Martin JF (2003) Adapation at specific loci. VII. Natural selection, dispersal and the diversity of molecular-functional variation patterns among butterfly species complexes (Colias: Lepidoptera, Pieridae). Mol Ecol 12:1265-1275

> Wiklund C, Fagerström T (1977) Why do males emerge before females? A hypothesis to explain the incidence of protandry in butterflies. Oecologia 31:153-158

Willmer P, Stone G, Johnston IA (2000) Environmental physiology of animals. Blackwell, Oxford

- Wilson RS, Franklin CE (2002) Testing the beneficial acclimation hypothesis. Trends Ecol Evol 17:66-70

> Wilson K, Cotter SC, Reeson AF, Pell JK (2001) Melanism and disease resistance in insects. Ecol Lett 4:637-649

> Yahara I (1999) The role of HSP90 in evolution. Genes Cells 4:375-379

Zeilstra I, Fischer K (2005) Cold tolerance in relation to developmental and adult temperature in a butterfly. Physiol Entomol 30:92-95

Proofs received from author(s): July 26, 2010 